\title{
Predictive physico-chemical model for soil quality index in a long-term green manure farming system at tropical conditions, North-eastern Brazil
}

\section{Gislaine dos Santos Nascimento}

Federal University of Paraiba

Tancredo Souza ( $\nabla$ tancredo_agro@hotmail.com )

Federal University of Paraiba https://orcid.org/0000-0001-8729-5478

Lucas Jónatan Rodrigues da Silva

Federal University of Paraiba

\section{Lídia Klestadt Laurindo}

Federal University of Paraiba

\section{Djail Santos}

Federal University of Paraiba

\section{Research Article}

Keywords: Green manure, Leguminous plant species, Long-term field experiment, Sandy soil, Soil quality index

Posted Date: April 6th, 2021

DOI: https://doi.org/10.21203/rs.3.rs-342176/v1

License: (c) (i) This work is licensed under a Creative Commons Attribution 4.0 International License. Read Full License 


\section{Abstract}

Soil quality index shed light on soil health and its capacity to sustain high primary production. It also can assist decision-making in farming systems by integrating this valuable product into soil management planning. However, the currently existing models are based on rather local data, and thus, there is a lack of predictive tools to monitor soil quality on farming systems at tropical conditions. We characterized soil physico-chemical properties, plant biomass production under a 6-year experiment in a sandy soil from Tropical ecosystem, using ten treatments: Brachiaria decumbens, Canavalia ensiformis, Crotalaria juncea, Crotalaria ochroleuca, Crotalaria spectabilis, Lablab purpureus, Mucuna pruriens, Neonotonia wightii, Pennisetum glaucum, and Stilozobium aterrimum. We found that most of the soil physico-chemical properties were correlated with each other by Pearson's correlation analysis. On the other hand, RDA illustrated that shoot dry biomass was related to soil $\mathrm{C}$ stock, $\mathrm{K}+$, macro- and microporosity. Soil $\mathrm{pH}, \mathrm{Al}^{3+}$, $\mathrm{Ca}^{2+}, \mathrm{Mg}^{2+}, \mathrm{K}^{+}$, Olsen's $\mathrm{P}, \mathrm{Na}^{+}$, soil $\mathrm{C}$ stock, bulk density, microporosity, macroporosity, and permanent wilting point were the main factors driving primary production in our long-term study. Our findings suggest that: 1) a consecutive green manure practice without any input of fertilizers after 6 years changed positively by increasing soil fertility (e.g., $\mathrm{Ca}^{2+}, \mathrm{Mg}^{2+}, \mathrm{K}^{+}$and Olsen's $\mathrm{P}$ ), and improving plant growth and soil quality in tropical savanna climate conditions; and 2) the 33 multivariate predictive models may provide a deeper view about the benefits of using plant species as green manure by creating positive plant-soil feedback thus promoting soil quality.

\section{Introduction}

The importance of the green manure farming system as a key management practice of both soil quality and ecosystem processes (e.g., soil organic matter inputs and nutrient cycling) at scales ranging from regional to global have been widely described (He et al. 2020; Khan et al. 2020). Among them, soil physical-chemical properties and net primary production (e.g., shoot and root biomass production) are especially relevant because of their environmental and economic importance (Fernández et al. 2020). Soil physical-chemical properties influence soil organism fitness, plant growth and biomass production (Cardone et al. 2020; Yang et al. 2020), increasing net primary production and creating a positive plantsoil feedback by improving litter deposition and recycling soil nutrients (Chen et al. 2020; Wang et al. 2020; Li et al. 2021). In green manure farming systems, two main effects are widely reported: (i) protecting soil surface thus acting as cover crops; and (ii) increasing soil organic matter when incorporated into soil profile (Gabriel et al. 2021; Torres et al. 2021). From an economic point of view, the use of green manure practice provides important benefits to smallholder farmers by reducing costs with fertilizers and other soil conditioners (Zhou et al. 2020). In fact, this practice reduces in $69 \%$ the overall costs with only organic fertilizers in certain regions such as the Brazilian Northeast (Nascimento et al. 2021).

Within this context, it is important to have accurate estimations of soil quality at tropical ecosystem, not only for smallholder farmers to integrate them into soil management planning, but also to comply with the low carbon agriculture requirements proposed by the Brazilian government (Stabile et al. 2020; 
Vinholis et al. 2021). Empirical models can contribute to these two tasks by providing quantitative understanding of the impact of several plant species cultivated as green manure on soil ecosystem, allowing to integrate the management of different plant species in existing management practices at the tropics (Sharma et al. 2021). In Brazil, different soil quality models at local and regional scales have been developed so far, mainly considering both soil chemical and biological database (dos Santos et al. 2021). Forstall-Sosa et al. (2020) developed a model for predicting soil quality as a function of abundance of Carabidae, Formicidae and Termitidae, shoot dry biomass, soil pH and available Olsen's $\mathrm{P}$ in green manure farming systems of Brazilian Northeast. Later, Kormann et al. (2021) developed similar model as a function of rainfall, soil pH, and abundance of Lumbricidae, Spirobolida and Staphylinidae for agroforestry systems and Mixed Ombrophilous Forest in Brazilian Southern. However, such models require a very trained taxonomist to classify an entire soil biota at Family level (Heydari et al. 2020). On the other hand, there is a lack of models enabling accurate enough prediction of soil quality. The main reason behind this problem is the difficulty to obtain constant quantities of data over long-term experiments, especially if the model considers possible changes in meteorological conditions (Andrade et al. 2020).

In this study, we have used data from a green manure farming system because this experiment is monitored for changes in soil physical, chemical, and biological properties using permanent plots established in tropical environment since 2014. Previous works have shown that cover crops used as green manure are key for improving soil organic carbon, shoot dry biomass production, and soil biota diversity and abundance (Souza et al. 2018; Melo et al. 2019; Forstall-Sosa et al. 2020; Nascimento et al. 2021). Leguminous plant species seem to promote a positive plant-soil feedback as described by Souza and Santos (2019). However, we need to understand the role of root biomass production into soil profile, and how it can contribute to soil quality. Thus, we hypothesized that (i) plant species with high root biomass production over a temporal scale may improve soil quality by promoting some physical and chemical properties as described by Laurindo et al. (2021); and (ii) soil quality index will follow certain soil-plant patterns and, therefore, the variability among plots in relation to plant, soil physical, and soil chemical properties was also studied as proposed by Sánchez-González et al. (2019).

The main aim of this study was to develop a predictive physico-chemical model for soil quality index in a long-term green manure farming system, taking into account plant dry biomass (shoot and root), soil pH, soil exchangeable cations $\left(\mathrm{K}^{+}, \mathrm{Na}^{+}, \mathrm{Ca}^{2+}, \mathrm{Mg}^{2+}, \mathrm{Al}^{3+}\right)$, sum of bases, cation exchange capacity (CEC), soil organic carbon, base saturation, soil bulk density, soil macro- and microporosity, total porosity, soil field capacity, permanent wilting point, available water content, soil aeration capacity, and soil available water capacity as explanatory variables. The predictive model was fitted for all the studied plant species (Brachiaria decumbens Stapf. cv. Basilisk, Canavalia ensiformis (L.) DC, Crotalaria juncea L, Crotalaria ochroleuca G. Don, Crotalaria spectabilis Roth, Lablab purpureus (L) Sweet, Mucuna pruriens (L) DC, Neonotonia wightii (Wight \& Arn.) J.A. Lackey, Pennisetum glaucum L, and Stilozobium aterrimum Piper \& Tracy), based on data from 50 permanent sample plots. 


\section{Material And Methods}

Sampling design and data collection

The study area was located at the "Chã-de-Jardim" Experimental Station, Agrarian Sciences Centre,

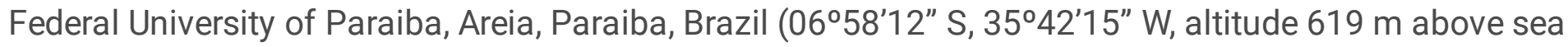
level). In total 50 permanent plots ( $24 \mathrm{~m}^{2}$ each plot) which were monitored since 2014 have been considered in this study. We have used the same treatments in each studied year (for more details about the studied treatments see Souza et al. 2018, Melo et al. 2019, Forstall-Sosa et al. 2020, Nascimento et al. 2021). Sampling was carried out in each studied year from July to December, and this study shows the results obtained until 2019. The climatic conditions of the study area are classified as tropical with drysummer characteristics (As-type climate following Köppen-Geiger climate classification), average annual precipitation, and mean air temperature of $1.300 \mathrm{~mm}$ and $+22.5^{\circ} \mathrm{C}$, respectively (Nascimento et al. 2021). The soil type of the studied site was classified as a Regosol with sandy loam texture (WRB 2006).

All the considered plots have been monitored during growing season (July to December), with data recorded for least 6 consecutive years. The field experiment was arranged in a randomized block design with five blocks and ten treatments (e.g., different plants species following a monocropping system per plot) (Table 1). The size of plots was $6 \times 4$ meters, with eight lines spaced of 0.5 meters. The seeding was realized rate of 400 seeds $\mathrm{m}^{-2}$ at $2 \mathrm{~cm}$ depth. We have analysed plant dry biomass production (shoot and root), soil physical, and soil chemical properties.

Table 1. Studied plant species (eight Fabaceae species and only two Poaceae species) used as green manure and their characteristics during the field experiment.

\begin{tabular}{|llll|}
\hline Plant species & Family & $\begin{array}{l}\text { Flowering } \\
\text { (days) }\end{array}$ & $\begin{array}{l}\text { Plant density (plants } \\
\text { plot }^{-1} \text { ) }\end{array}$ \\
\hline Brachiaria decumbens Stapf. & Poaceae & $150-180$ & 480 \\
\hline Canavalia ensiformis (L) DC & Fabaceae & $62-70$ & 480 \\
\hline Crotalaria juncea L & Fabaceae & $53-56$ & 240 \\
\hline Crotalaria ochroleuca G. Don & Fabaceae & $52-58$ & 240 \\
\hline Crotalaria spectabilis Roth & Fabaceae & $72-78$ & 240 \\
\hline Dolichos lablab $($ L) Sweet & Fabaceae & $87-95$ & 480 \\
\hline Mucuna pruriens (L) DC & Fabaceae & $121-124$ & 240 \\
\hline $\begin{array}{l}\text { Neonotonia wightii (Wight \& Arn.) J.A. } \\
\text { Lackey }\end{array}$ & Fabaceae & $69-75$ & 480 \\
\hline Pennisetum glaucum L & Poaceae & $60-66$ & 480 \\
\hline Stilozobium aterrimum Piper \& Tracy & Fabaceae & $119-124$ & 480 \\
\hline
\end{tabular}


Shoot dry biomass production from each studied plot was recorded for 6 consecutive years and this variable was estimated as described by Forstall-Sosa et al. (2020). Initially, we have selected ten plants per plot with homogenous characteristics of plant height and diameter near soil surface. Subsequently, all plants were harvested at $5-\mathrm{cm}$ above the soil surface and the shoot dry biomass of these ten plants was used to estimated plant biomass production in $\mathrm{kg} \mathrm{ha}^{-1}$. For root dry biomass, we used the method to collect soil monoliths $(20 \times 20 \times 20 \mathrm{~cm})$ as described by Souza and Santos $(2018)$. We collected ten soil monoliths in each studied plot. After that, we wrapped them with plastic film and transported all the monoliths with minimal disturbance until analysis. During our analysis, and to estimate root dry biomass, we collected roots from the soil monoliths. Roots in these layers were washed using a 0.5 -mm nylon mesh bag. Shoot and root dry biomass (g) was determined after drying the samples for $48 \mathrm{~h}$ at $65^{\circ} \mathrm{C}$.

\section{Soil physico-chemical properties}

Soil samples with disturbed and undisturbed structure were collected in all plot 90 days after the plant species were incorporated to soil profile. The soil samples with undisturbed structure (e.g., soil samples collected using metallic cylinders with $100 \mathrm{~cm}^{3}$ each) were used to determine the soil physical properties. While the disturbed samples were used to determine soil chemical properties. The disturbed soil samples were packed separately in plastic bags, air-dried, and passed through a $2 \mathrm{~mm}$ mesh sieve (Teixeira et al. 2017). The soil parameters evaluated were soil $\mathrm{pH}$, soil exchangeable cations $\left(\mathrm{K}^{+}, \mathrm{Na}^{+}\right.$, $\mathrm{Ca}^{2+}, \mathrm{Mg}^{2+}, \mathrm{Al}^{3+}$ ), sum of bases, cation exchange capacity (CEC), soil organic carbon, base saturation, soil bulk density, soil microporosity, total porosity, soil macroporosity, soil field capacity, permanent wilting point, available water content, soil aeration capacity, and soil available water capacity. Details of methods used to measure each treatment can be found in Nascimento et al. (2021).

\section{Statistical analysis}

All data was analysed with using R statistical software (R Core Team 2018). Pearson's correlation between soil physico-chemical properties and plant fitness (e.g., shoot and root dry biomass production) was tested using the rcorr function from the Hmisc package to examine the bivariate correlation between soil properties and plant fitness (e.g., shoot and root dry biomass) with data from all the studied years and plots. Next, we arcsin square root transformed all dependent variables to meet assumption of normal distributions. We created predictive models using the step function in the stats package to verify the effect of individual or combined variables (soil physico-chemical properties, shoot dry biomass, and root dry biomass) on each specific studied variable. We also used treatment (e.g., the studied plant species used as green manure) and the years of their cultivation as fixed effect as described by Rosenfield and Müller (2020). Plots and blocks were included as a random effect in each model. 
An explanatory principal component analysis was performed to explore all variability among years with respect to explore the effects of the studied plant species on soil properties and plant biomass production. The PCA were conducted with $r d a$ function in the vegan package. A soil quality index was calculated using the PCA-LSF-SQIw approach as described by Forstall-Sosa et al. (2020), which combines soil physical and chemical characteristics, and plant biomass production measured at all studied plots. Based on this approach we developed a model (Eq. 1) to determine the soil quality index (SQI). High values of ISQ indicated a high-class soil that provides plant biomass production, soil structure without negative effects to soil ecosystem.

Eq.1 SQI $=(53.94 \times \mathrm{N}-\mathrm{R})+(27.37 \times \mathrm{N}-\mathrm{P})+(5.43 \times \mathrm{N}-\mathrm{S})+(3.17 \times \mathrm{N}-\mathrm{Ca})+(2.15 \times \mathrm{N}-\mathrm{K})+(1,731 \times$ $N-$ SCS) +6.22

Where: $\mathrm{N}-\mathrm{R}=$ Normalized values of root dry biomass $\left(\mathrm{g} \mathrm{cm}^{-3}\right), \mathrm{N}-\mathrm{P}=$ Normalized values of Olsen's available $\mathrm{P}\left(\mathrm{mg} \mathrm{dm}^{-3}\right), \mathrm{N}-\mathrm{S}=$ Normalized values of shoot dry biomass $\left(\mathrm{t} \mathrm{ha}^{-1}\right), \mathrm{N}-\mathrm{Ca}=$ Normalized values of exchangeable $\mathrm{Ca}\left(\mathrm{cmol}_{\mathrm{C}} \mathrm{dm}^{-3}\right), \mathrm{N}-\mathrm{K}=$ Normalized values of exchangeable $\mathrm{K}\left(\mathrm{cmol}_{\mathrm{C}} \mathrm{dm}^{-3}\right)$, and $\mathrm{N}$ - SCS $=$ Normalized values of soil carbon stock $\left(\mathrm{t} \mathrm{C} \mathrm{ha}^{-1}\right)$. All normalized values were obtained dividing the mean of each component by their scores obtained in a PCA analysis.

\section{Results}

Pearson's correlation showed that most of the soil physico-chemical properties were correlated with each other (Fig. 1). Soil pH was positively correlated with exchangeable $\mathrm{Ca}(p<0.001)$, exchangeable $\mathrm{Mg}(p<$ $0.001)$, available Olsen's $P(p<0.001)$, sum of bases $(p<0.001)$, soil carbon stock $(p<0.001)$, and bulk density $(p<0.001)$, whereas it was negatively correlated with exchangeable Al $(p<0.001)$, exchangeable $\mathrm{Na}(p<0.001), \mathrm{H}^{+}+\mathrm{Al}^{3+}(p<0.01)$, shoot dry biomass $(p<0.05)$, root dry biomass $(p<0.05)$, and physical properties $(p<0.001)$ except bulk density and microporosity. Exchangeable Al was positively correlated with exchangeable $\mathrm{Na}(p<0.001)$, and $\mathrm{H}^{+}+\mathrm{Al}^{3+}(p<0.001)$, whereas it was negatively correlated with exchangeable Ca $(p<0.001), \mathrm{K}(p<0.01)$, available Olsen's $\mathrm{P}(p<0.01)$, sum of bases $(p<0.001)$, base saturation $(p<0.001)$, root dry biomass $(p<0.05)$, and soil microporosity $(p<0.05)$. Exchangeable Ca was positively correlated with available Olsen's $\mathrm{P}(p<0.001)$, sum of bases $(p<0.001)$, CEC $(p<0.001)$, base saturation $(p<0.01)$, root dry biomass $(p<0.05)$, and bulk density $(p<0.01)$, whereas it was negatively correlated with exchangeable $\mathrm{Na}(p<0.001)$, soil organic carbon $(p<0.01)$, soil carbon stock $(p<0.01)$, and all physical properties $(p<0.001)$ except bulk density and soil microporosity.

Exchangeable Mg was positively correlated with available Olsen's P, sum of bases $(p<0.001), \operatorname{CEC}(p<$ $0.001)$, base saturation $(p<0.001)$, and bulk density $(p<0.001)$, whereas it was negatively correlated with exchangeable $\mathrm{Na}(p<0.05), \mathrm{H}^{+}+\mathrm{Al}^{3+}(p<0.01)$, and all physical properties $(p<0.001)$ except soil microporosity. Exchangeable K was positively correlated with exchangeable $\mathrm{Na}(p<0.01)$, base saturation $(p<0.001)$, soil organic carbon $(p<0.01)$, soil carbon stock $(p<0.001)$, shoot dry biomass $(p<$ $0.001)$, and all physical properties $(p<0.001)$ except bulk density and soil microporosity, whereas Exchangeable $\mathrm{K}$ was negatively correlated with $\mathrm{H}^{+}+\mathrm{Al}^{3+}(p<0.001), \mathrm{CEC}(p<0.01)$, root dry biomass $(p<$ 
$0.05)$, and bulk density $(p<0.01)$. Available Olsen's $P$ was positively correlated with sum of bases $(p<$ $0.001)$, base saturation $(p<0.001)$, and bulk density $(p<0.01)$, whereas it was negatively correlated with exchangeable $\mathrm{K}(p<0.001), \mathrm{H}^{+}+\mathrm{Al}^{3+}(p<0.001)$, soil organic carbon $(p<0.05)$, root dry biomass $(p<$ $0.01)$, and all physical properties $(p<0.001)$, except bulk density and soil microporosity. Exchangeable $\mathrm{Na}$ was positively correlated with $\mathrm{H}^{+}+\mathrm{Al}^{3+}(p<0.05)$, soil organic carbon $(p<0.001)$, soil carbon stock $(p<$ $0.001)$, root dry biomass $(p<0.01)$, and all physical properties $(p<0.001)$ except bulk density and soil microporosity, whereas exchangeable Na was negatively correlated with sum of bases $(p<0.001)$, CEC ( $p$ $<0.01)$, base saturation $(p<0.001)$, and bulk density $(p<0.001) . \mathrm{H}^{+}+\mathrm{Al}^{3+}$ was positively correlated with CEC $(p<0.001)$, root dry biomass $(p<0.05)$, field capacity $(p<0.05)$, and permanent wilting point $(p<$ $0.01)$, whereas it was negatively correlated with sum of bases $(p<0.01)$, base saturation $(p<0.001)$, and soil microporosity $(p<0.05)$. Sum of bases was positively correlated with CEC $(p<0.001)$, base saturation $(p<0.001)$, and bulk density $(p<0.001)$, whereas it was negatively correlated with soil organic carbon $(p<0.05)$, root dry biomass $(p<0.01)$, and all physical properties $(p<0.001)$ except bulk density. CEC was positively correlated with bulk density $(p<0.01)$, whereas it was negatively correlated with shoot dry biomass $(p<0.05)$, and all physical properties $(p<0.01)$, except bulk density. Base saturation was negatively correlated with root dry biomass $(p<0.01)$, all physical properties $(p<0.01)$ except soil microporosity. Soil organic carbon was positively correlated with soil carbon stock $(p<0.001)$, shoot dry biomass $(p<0.001)$, and all physical properties except bulk density, which had a negative correlation with it $(p<0.001)$. Soil carbon stock was positively correlated with shoot dry biomass $(p<0.01)$, and all physical properties $(p<0.05)$ except bulk density, whereas it was negatively correlated with bulk density $(p<0.05)$. Shoot dry biomass was positively correlated with all physical properties $(p<0.001)$ except bulk density which presented a negative correlation with it $(p<0.05)$. Root dry biomass was positively correlated with all physical variables $(p<0.001)$ except bulk density, and soil macro- and microporosity. Bulk density was negatively correlated with all physical variables $(p<0.001)$ except soil microporosity. Microporosity was positively correlated with all physical properties $(p<0.01)$. Finally, the remain physical properties (e.g., soil macroporosity, soil porosity, field capacity, permanent wilting point, available water content, soil aeration capacity, and soil available water capacity) were positively correlated to each other (Fig. 1).

Redundancy analyses (RDA) illustrated that shoot dry biomass was related to soil C stock, exchangeable K (Fig. 2 a), macroporosity, and microporosity (Fig. 2b). All chemical and physical properties could explain 74.26 and $69.59 \%$, respectively of primary production variation (Monte Carlo permutation test with 999 permutation, $p<0.001)$. Conditional effects show that the main factors driving primary production were soil $\mathrm{pH}$, exchangeable $\mathrm{Al}$, exchangeable $\mathrm{Ca}$, exchangeable $\mathrm{Mg}$, exchangeable $\mathrm{K}$, available Olsen's P, exchangeable Na, soil C stock (Fig. 2a), bulk density, microporosity, macroporosity, and permanent wilting point (Fig. 2b)

Based on the results obtained by stepwise procedure, we created 33 multivariate predictive models to estimate primary production (e.g., shoot and root dry biomass production) and soil physico-chemical properties as a function of plant species (treatments), studied years and the interaction between plant dry 
biomass production and changes into soil physico-chemical properties in tropical ecosystem. All the proposed models showed significant differences between treatments and years for several studied variables (Table 2).

Table 2. Predictive models between physico-chemical properties and primary production 
Model

F-value Significance $\mathrm{R}^{2}{ }_{\text {adj }}$

Soil $\mathrm{pH} \sim \mathrm{Ca}+\mathrm{Mg}+\mathrm{K}+\mathrm{Na}+$ treatment + year

$16.25<0.001$

0.21

Soil pH $\sim$ Field capacity + Permanent wilting point + SAC + Soil porosity + treatment + year

$13.76<0.001 \quad 0.30$

Exchangeable $\mathrm{Al} \sim$ Exchangeable $\mathrm{Na}+\left(\mathrm{H}^{+}+\mathrm{Al}^{3+}\right)+$ treatment +

24.15

$<0.001$

0.28 year

Exchangeable $\mathrm{Al} \sim$ Exchangeable $\mathrm{Ca}+$ Exchangeable $\mathrm{K}+$ Base saturation + Microporosity + treatment + year

Exchangeable Ca Olsen's P + CEC + Base saturation + treatment + year

Exchangeable $\mathrm{Ca} \sim$ Exchangeable $\mathrm{Na}+\mathrm{SAC}+$ treatment + year

Exchangeable Mg Available P + Sum of bases + CEC + Base saturation + treatment + year

Exchangeable $\mathrm{Mg} \sim$ Exchangeable $\mathrm{Na}+\left(\mathrm{H}^{+}+\mathrm{Al}^{3+}\right)+\mathrm{SAC}+$ treatment + year

Exchangeable $\mathrm{K} \sim$ Exchangeable $\mathrm{Na}+$ Base saturation + SOC + Shoot dry biomass + treatment + year

$18.11<0.001 \quad 0.36$

$36.81<0.001$

Exchangeable $\mathrm{K} \sim\left(\mathrm{H}^{+}+\mathrm{Al}^{3+}\right)+$ Root dry biomass + Bulk density + 10.61

25.91

$<0.001$

27.63

$<0.001$ treatment + year

Olsen's P Sum of bases + Base saturation + Bulk density + treatment + year

20.09

$<0.001$

Olsen's $\mathrm{P} \sim\left(\mathrm{H}^{+}+\mathrm{Al}^{3+}\right)+$ Field capacity + treatment + year

17.42

$<0.001$
Exchangeable Na $\sim \mathrm{SOC}+$ Soil C stock + Microporosity + Field capacity + SAC + treatment + year

Exchangeable $\mathrm{Na} \sim$ Sum of bases + CEC + Base saturation + Bulk density + treatment + year
$\left(\mathrm{H}^{+}+\mathrm{Al}^{3+}\right) \sim$ Permanent wilting point + treatment + year
4.72
$\left(\mathrm{H}^{+}+\mathrm{Al}^{3+}\right) \sim$ Sum of bases + Base saturation + Microporosity +
694. treatment + year

29.42

$44.50<0.001$

$<0.001$

0.32

14.30

$<0.001$

0.64

Sum of bases $\sim$ CEC + Base saturation + treatment + year

Sum of bases $\sim$ SOC + Macroporosity + Microporosity + Permanent wilting point $+\mathrm{SAC}+$ treatment + year

$\mathrm{CEC} \sim$ Bulk density + treatment + year

6.17

3306

$<0.001$

0.98

$\mathrm{CEC} \sim \mathrm{AWC}+\mathrm{SAC}+$ treatment + year

18.40

26.95

$<0.001$

0.52

Base saturation $\sim$ Root biomass + Microporosity +

16.07

$<0.001$

0.04

Page 9/21 
year

Soil porosity + Permanent wilting point $+\mathrm{SAC}+$ treatment +

SOC Soil C stock + Bulk density + Shoot biomass +

$1269.09<0.001$

0.98

Field capacity $+A W C+$ treatment + year

Soil C stock Bulk density + Shoot biomass + Microporosity +

8.56

$<0.001$

Field capacity $+A W C+$ treatment + year

Shoot biomass $\sim$ Bulk density + Field capacity + Permanent

wilting point $+\mathrm{SAC}+$ treatment + year

8.87

$<0.001$

0.20

Root biomass $\sim$ Permanent wilting point + AWC + SAC +

7.51

$<0.001$

0.14

treatment + year

Bulk density Microporosity + Soil porosity + SAC + treatment $+\quad 37.66 \quad<0.001 \quad 0.48$ year

Microporosity Macroporosity + Soil porosity +

$1383.00<0.001$

Field capacity + treatment + year

Macroporosity $\sim$ SAC + treatment + year

$106.4<0.001$

0.46

Soil porosity $\sim$ SAC + treatment + year

$318.1<0.001$

0.72

Field capacity $\sim$ Permanent wilting point + AWC + treatment + year

$9251.00<0.001$

0.99

Permanent wilting point $\sim$ AWC + SAC + treatment + year

924.7

$<0.001$

0.93

AWC $\sim$ SAWC + CAS + treatment + year

$8223.02<0.001$

0.99

SAWC $\sim$ SAC + treatment + year

$1221.02<0.001$

0.91

Soil biological quality index was reduced when $C$. juncea, $C$. ochroleuca, and $P$. glaucum plants were cultivated in our experiment. We found the highest values of soil biological quality index on the plots where $N$. wightii was cultivated $(628.65 \pm 109.57)$. There were no significant differences between $C$. ensiformis, C. spectabilis, D. lablab, M. pruriens, and $S$. aterrimum on soil quality index. Overall, the soil biological quality index was affected positively by all the studied plant species after 6 years of their cultivation and incorporation into soil profile (Fig. 3).

\section{Discussion}

Our results emphasize the long-term influence of different plant species used as green manure on soil physico-chemical properties, plant biomass production (e.g., shoot and root), and soil quality in a Tropical ecosystem. Essentially, we wanted to understand how the biomass incorporation of green manure into soil profile created a positive plant-soil feedback by improving soil properties without any input of fertilizers or soil conditioners on soil quality. Our results revealed significant correlations between all studied variables including soil ecosystem (represented by soil physico-chemical properties) and 
primary production (represented by shoot and root dry biomass production). Accordingly, to the studies done by Souza et al. (2018) and Melo et al. (2019), plant species used as green manure such as leguminous plant species can promote positive changes in soil physico-chemical properties by increasing soil C stock, nutrient cycling, soil water infiltration, and soil aeration capacity, especially when their plant residue is fully incorporated into soil profile (Austin et al. 2017, Demir and Işık, 2019; Ashworth et al. 2019). In our study, we found that plant species used as green manure, such as $N$. wightii, that showed in all studied years high root biomass production, and have improved soil available $\mathrm{P}, \mathrm{Ca}^{2+}, \mathrm{K}^{+}$, and soil $\mathrm{C}$ stock through its biomass incorporation into soil profile. These results agree with previous studies done by Nascente and Stone (2018), Souza et al. (2018), and Mortensen et al. (2021), which reported that soil ecosystems with constant nutrient-rich organic amendments may increase soil physico-chemical properties (e.g., soil organic carbon, $\mathrm{Ca}^{2+}$, available $\mathrm{P}$, bulk density, and soil porosity).

In fact, the green manure practice has the ability to change both soil physical and chemical soil properties due to the high biomass production on soil surface (e.g., at this point the green manure plants act as cover crops protecting soil surface from erosion) and their biomass incorporation into soil profile (e.g., here promoting rhizodeposition, nutrient cycling), thus resulting in a healthy soil environment from the subsequent annual plant species (Pacheco et al. 2017; Hirte et al. 2018; Çerçioğlu et al. 2019; Oliveira et al. 2020; Hu and Chabbi, 2021; Liu et al. 2021; Mortensen et al. 2021). Our results highlight the importance of considering the green manure practice as an alternative way to input organic resources (Haruna et al. 2020). It may act as a driver for improving the soil physical-chemical properties as we have found in our predictive models especially if we are considering the effect of the green manure practice over the years (in our study 6 years of continuous use of the green manure). Ours results showed that microporosity, macroporosity, soil C stock and exchangeable Al were strongly correlated with root dry biomass. Plant species with high root biomass production (e.g., N. wightii and B. decumbens) can improve rootability (e.g., by releasing exudates and $\mathrm{H}^{+}$), create biopores, thus influencing soil microbial activity and soil porosity (Restovich et al. 2019), also these plant species may affect the rhizodeposition around the rhizosphere by the allocation of $\mathrm{N}$ - and $\mathrm{C}$-rich compounds as described by Redin et al. (2018). According to the study done by Rossi et al. (2020), plant roots may influence the input of soil organic carbon into soil profile, for example, Poaceae presents high fine roots production (e.g., lignin and cellulose rich) which are slowly decomposed by soil organisms, while Fabaceae presents faster fine roots production and decomposition (Jo et al. 2020; Forstall-Sosa et al. 2020). For shoot dry biomass, we found significative correlation with bulk density, Olsen's $\mathrm{P}$, and soil pH. These results may be related with the high both plant residue deposition and incorporation which may change the soil bulk density and lead to improve the soil aeration capacity, soil structure, and soil nutrient contents (Adekiya et al. 2019; Islam et al. 2019; Zhang et al. 2019).

For soil quality index, the Fabaceae plant species showed highest values for green manure when compared with Poaceae plant species. Fabaceae plant species produce nitrogen inputs, thus improving biogeochemical cycles (Pereira et al. 2018). Besides that, legume green manures (e.g., Fabaceae species) contributes to the nutrient balance and consequent restore crop productivity. Their capacity to fix 
atmospheric nitrogen decreases the $\mathrm{C}: \mathrm{N}$ ratio, resulting in faster residue decomposition and consequent release of $\mathrm{N}, \mathrm{P}$ and $\mathrm{K}$ to the soil. The $\mathrm{P}$ release occurs in a labile form that enhances $\mathrm{P}$ nutrition of succeeding crops. Therefore, the Fabaceae green manure increase soil fertility levels over time. (Karuku et al. 2019). N. wightii is one of the most representative in Fabaceae Family in our long-term study. We found that $N$. wightii provided the highest values for soil quality index (Jain et al. 2018). In our plots, we observed that $N$. wightii developed a very dense perennial root system during the six years of our experiment, in addition this plant species showed an extraordinary regrowth capacity (Xavier and Vieira et al. 2018). These factors make the species more advantageous, reflecting in a high soil quality index. The highest values of $N$. wightii for soil quality index also relates to production a high quantity of fine roots since the principal predictor of soil quality index was the fine roots production. The nitrogen accumulation for legumes green manure varies according with soil fertility, soil water availability and legumes species (Armstrong et al. 2018, Wang et al. 2018, Dayoub et al. 2017), which may explain the low values of soil quality index for $C$. juncea. The low dry matter accumulation provided by $P$. glaucum reflected for low soil quality index for this species (Teófilo et al. 2020).

\section{Conclusions}

The green manure practice over a long-term experiment determined positive changes in soil physicochemical properties and plant biomass production in a tropical ecosystem. The use of $N$. wightii showed the highest soil quality index by improving root biomass production, available $\mathrm{P}, \mathrm{Ca}^{2+}, \mathrm{K}^{+}$, and soil $\mathrm{C}$ stock on a tropical sandy soil under field conditions. Our findings suggest that these plant species have positive effects on soil fertility, soil hydraulic properties, and primary production as described by the thirty-three proposed predictive models. The results of our study highlight the importance of considering plant species from both Poaceae and Fabaceae family used as green manure as soil conditioner, and thus creating a positive plant-soil feedback. Thus, long-term experiments considering our models may exploit all the correlation between all soil physico-chemical variables, primary production, soil hydraulic properties, and soil quality.

\section{Declarations}

\section{Author's contributions}

We declare that all the authors made substantial contributions to the conception, design, acquisition, analysis, and interpretation of the data. All the authors participate in drafting the article, revising it critically for important intellectual content; and finally, the authors gave final approval of the version to be submitted to Journal of Soil and Sediments through transfer desk service.

\section{Compliance with ethical standards}

The authors declare that they have no conflict of interest. 


\section{References}

Andrade VHGZ, Redmile-Gordon M, Barbosa BHG, Andreote FD, Roesch, LFW, Pylro VS (2020). Artificially intelligent soil quality and health indices for "next generation" food production systems. Trends in Food Science \& Technology. https://doi.org/10.1016/j.tifs.2020.10.018

Adekiva AO, Agbede TMA, Aboyeji CMA, Dunsin O, Ugbe JO (2019) Green manures and NPK fertilizer effects on soil properties, growth, yield, mineral and vitamin $\mathrm{C}$ composition of okra (Abelmoschus esculentus (L.) Moench). Journal of the Saudi Society of Agricultural Sciences 18(2):218-223. https://doi.org/10.1016/j.jssas.2017.05.005

Armstrong RD, Perris R, Munn M, Dunsford K, Robertson F, Hollaway GJ, O'Leary GJ (2018) Effects of long-term rotation and tillage practice on grain yield and protein of wheat and soil fertility on a Vertosol in a medium-rainfall temperate environment. Crop and Pasture Science 70(1):1-15. https://doi.org/10.1071/CP17437

Ashworth AJ, Owens PR, Allen FL (2019) Long-term cropping systems management influences soil strength and nutrient cycling. Geoderma. https://doi.org/10.1016/j. Geoderma.2019.114062

Austin EE, Wickings K, McDaniel MD, Robertson GP, Grandy AS (2017) Cover crop root contributions to soil carbon in a no-till corn bioenergy cropping system. GCB Bioenergy 9(7): 1252-1263. https://doi.org/10.1111/gcbb.12428

Cardone L, Castronuovo D, Perniola M, Scrano L, Cicco N, Candido V (2020) The Influence of Soil Physical and chemical properties on saffron (Crocus sativus L.) growth, yield and quality. Agronomy, 10(8), 1154 . https://doi.org/10.3390/agronomy10081154

Çerçioğlu M, Anderson SH, Udawatta RP, Alagele S (2019) Effect of cover crop management on soil hydraulic properties. Geoderma 343:247-253. https://doi.org/10.1016/j.geoderma.2019.02.027

Chen H, Zhao X, Lin Q, Li G, Kong W. (2020). Spring watering interactively improves aboveground net primary productivity and soil microbial biomass in a semi-arid grassland of China. Catena, 189, 104478. https://doi.org/10.1016/j.catena.2020.104478

Dayoub E, Naudin C, Piva G, Shirtliffe SJ, Fustec J, Corre-Hellou G (2017) Traits affecting early season nitrogen uptake in nine legume species. Heliyon 3(2). https://doi.org/10.1016/j.heliyon.2017.e00244

Demir Z and Işık D (2019) Effects of cover crops on soil hydraulic properties and yield in a persimmon orchard. Bragantia 78(4):596-605. https://doi.org/10.1590/1678-4499.2010197

dos Santos WP, Silva MLN, Avanzi JC, Acuña-Guzman SF, Cândido BM, Cirillo MÂ, Curi N (2021) Soil quality assessment using erosion-sensitive indices and fuzzy membership under different cropping systems on a Ferralsol in Brazil. Geoderma Regional, e00385.

https://doi.org/10.1016/j.geodrs.2021.e00385

Page 13/21 
Fernández M, Alaejos J, Andivia E, Madejón P, Díaz MJ, Tapias R (2020). Short rotation coppice of leguminous tree Leucaena spp. improves soil fertility while producing high biomass yields in Mediterranean environment. Industrial Crops and Products. https://doi.org/10.1016/j.indcrop.2020.112911

Forstall-Sosa KS, Souza TAF, Lucena EO, Silva, SIA, Ferreira JT, Silva TN, Santos D, Niemeyer JC (2020) Soil macroarthropod community and soil biological quality index in a green manure farming system of the Brazilian semi-arid. https://doi.org/10.2478/s11756-020-00602-y

Gabriel JL, García-González I, Quemada M, Martin-Lammerdinga D, Alonso-Ayuso M, Hontoria C (2021) Cover crops reduce soil resistance to penetration by preserving soil surface water contente. Geoderma. https://doi.org/10.1016/j.geoderma.2020.114911

Haruna SI, Anderson SH, Udawatta RP, CJ Gantzer, Phillips NC, Cui S, Gao Y (2020) Improving soil physical properties through the use of cover crops: A review. https://doi.org/10.1002/agg2.20105

He, HB, Li WX, Zhang YW, Cheng JK, Jia XY, Li S, Yang H, Chen B, Xin GR (2020). Effects of Italian ryegrass residues as green manure on soil properties and bacterial communities under an Italian ryegrass (Lolium multiflorum L.)-rice (Oryza sativa L.) rotation. Soil and Tillage Research, 196, 104487. https://doi.org/10.1016/j.still.2019.104487

Heydari M, Eslaminejad P, Kakhki FV, Mirab-balou M, Omidipour R, Prévosto B, Lucas-Borja ME (2020) Soil quality and mesofauna diversity relationship are modulated by woody species and seasonality in semiarid oak forest. Forest Ecology and Management. https://doi.org/10.1016/j.foreco.2020.118332

Hirte J, Leifeld J, Abiven S, Oberholzer HR, Mayer J (2018) Below ground carbon inputs to soil via root biomass and rhizodeposition of field-grown maize and wheat at harvest are independent of net primary productivity. Agric Ecosyst Environ 265:556-566. https://doi.org/10.1016/j.agee.2018.07.010

Hu T and Chabbi A (2021) Does the higher root carbon contribution to soil under cropping cycles following grassland conversion also increase shoot biomass? Science of The Total Environment. https://doi.org/10.1016/j.scitotenv.2020.141684

Islam MM, Urmi TA, Rana MS, Alam MS, Haque MM (2019) Green manuring effects on crop morphophysiological characters, rice yield and soil properties. Physiol Mol Biol Plants 25:303-312. https://doi.org/10.1007/s12298-018-0624-2

Jain MS, Jambhulkar R, Kalamdhad AS (2018) Biochar amendment for batch composting of nitrogen rich organic waste: Effect on degradation kinetics, composting physics and nutritional properties. Bioresource Technology 253:204-213. https://doi.org/10.1016/j.biortech.2018.01.038

Karuku GN, Onwonga RN, Chepkemoi J, Kathumo VM (2019) Effects of Tillage Practices, Cropping Systems and Organic Inputs on Soil Nutrient Content in Machakos County. Journal of Agriculture and 
Sustainability 12(1):13-46. https://doi.org/10.5897/AJAR2018.13444

Khan MI, Gwon HS, Alam MA, Song HJ, Das S, Kim PJ. (2020). Short term effects of different green manure amendments on the composition of main microbial groups and microbial activity of a submerged rice cropping system. Applied Soil Ecology, 147, 103400.

https://doi.org/10.1016/j.apsoil.2019.103400

Laurindo LK, Souza T, da Silva LJR, Casal TB, Pires KJC, Kormann S, Schmitt DE, Siminski A (2021) Arbuscular mycorrhizal fungal community assembly in agroforestry systems from the Southern Brazil. Biologia. https://doi.org/10.1007/s11756-021-00700-5

Li H, Yao Y, Zhang X, Zhu H, Wei X. (2021). Changes in soil physical and hydraulic properties following the conversion of forest to cropland in the black soil region of Northeast China. Catena, 198, 104986. https://doi.org/10.1016/j.catena.2020.104986

Liu R, Thomas BW, Shi X, Zhang X, Wang Z, Zhang Y (2021) Effects of ground cover management on improving water and soil conservation in tree crop systems: A meta-analysis. Catena. https://doi.org/doi:10.1016/j.catena.2020.105085

Kormann S, Souza TAF, Laurindo LK, Silva LJR, Lucena EO, Silva SAI, Barbosa LS (2021) Land use and soil properties changes soil fauna community composition in subtropical ecosystems. Tropical Ecology, (In press).

Melo LN, Souza TAF, Santos D (2019) Transpiratory rate, biomass production, and leaf macronutrient content of different plant species cultivated on a Regosol in the Brazilian semiarid. Russian Agricultural Sciences 45(2):147-153. https://doi.org/10.3103/S1068367419020150

Mortensen EO, Notaris CD, Peixoto L, Olesen J E, Rasmussen J (2021) Short-term cover crop carbon inputs to soil as affected by long-term cropping system management and soil fertility. Agriculture, Ecosystems \& Environment. https://doi.org/10.1016/j.agee.2021.107339

Nascimento GS, Souza TAF, Silva LJR, Santos D (2021) Soil physico-chemical properties, biomass production, and root density in a green manure farming system from tropical ecosystem, North-eastern Brazil. J Soils Sediments. https://doi.org/10.1007/s11368-021-02924-z

Nascente AS and Stone LF (2018) Cover Crops as Affecting Soil Chemical and Physical Properties and Development of Upland Rice and Soybean Cultivated in Rotation. Rice Science 25(6):340-349. https://doi.org/10.1016/j.rsci.2018.10.004

Oliveira FCC, Ferreira GWD, Souza JLS, Vieira MEO, Pedrotti A (2020) Soil physical properties and soil organic carbon content in northeast Brazil: long-term tillage systems effects Sci Agric 77(4). http://dx.doi.org/10.1590/1678-992X-2018-0166 
Pacheco LP, Monteiro MMS, Petter FA, Nóbrega JCA, Santos AS (2017) Biomass and nutrient cycling by cover crops in Brazilian Cerrado in the state of Piauí. Rev Caatinga 30(1):13-23.

https://doi.org/10.1590/1983-21252017v30n102rc

Pereira APA, ZAgatto MRG, Brandani CB, Mescolotti DL, Cotta SR, Gonçalves JLM, Cardoso EJBN (2018) Acacia Changes Microbial Indicators and Increases $\mathrm{C}$ and $\mathrm{N}$ in Soil Organic Fractions in Intercropped Eucalyptus Plantations. Front Microbiol. https://doi.org/10.3389/fmicb.2018.00655

R Core Team (2018) R: A Language and Environment for Statistical Computing. R Foundation for Statistical Computing, Vienna, Austria. https://www.R-project.org/

Redin M, Recous S, Aita C, Chaves B, Pfeifer IC, Bastos LM, Pilecco GE, Giacomini SJ (2018) Root and Shoot Contribution to Carbon and Nitrogen Inputs in the Topsoil Layer in No-Tillage Crop Systems under Subtropical Conditions. Rev Bras Cienc Solo. https://dx.doi.org/10.1590/18069657rbcs20170355

Restovich SB, Andriulo AE, Armas-Herrera CM, Beribe MJ, Portela IS (2019) Combining cover crops and low nitrogen fertilization improves soil supporting functions. Plant Soil 442:401-417. https://doi.org/10.1007/s11104-019-04205-8

Rosenfield MF, Müller SC (2020) Plant traits rather than species richness explain ecological processes in subtropical forests. Ecosystems 23: 52-66. https://doi.org/10.1007/s10021-019-00386-6

Rossi LMW, Mao Z, Merino-Martín L, Roumet C, Fort F, Taugourdeau O, Boukcim H, Fourtier S, ReyGranado M, Chevallier T, Cardinael R, Fromin N, Stokes A (2020). Pathways to persistence: plant root traits alter carbon accumulation in different soil carbon pools. Plant and soil 452:457-478. https://doi.org/10.1007/s11104-020-04469-5

Sánchez-González M, de-Miguel S, Martin-Pinto P, Martinez-Peña F, Pasalodos-Tato M, Oria-de-Rueda JÁ, Aragón JM, Cañellas I, Bonet JA (2019) Yields models for predicting aboveground ectomycorrhizal fungal productivity in Pinus sylvestris and Pinus pinaster stands of northern Spain. Forest Ecosystems 6: 52. https://doi.org/10.1186/s40663-019-0211-1

Sharma S, Saikia R, Thind HS, Singh Y, Jat M. (2021). Tillage, green manure and residue management accelerate soil carbon pools and hydrolytic enzymatic activities for conservation agriculture based ricewheat systems. Communications in Soil Science and Plant Analysis.

https://doi.org/10.1080/00103624.2020.1862147

Souza AVSS, Souza TAF, Santos D, Rios ES, Souza GJL (2018) Agronomic evaluation of legume cover crops for sustainable agriculture. Russ Agric Sci 44:31-38.

https://doi.org/10.3103/S1068367418010093

Souza TAF, Santos D (2018) Effects of using different host plants and long-term fertilization systems on population sizes of infective arbuscular mycorrhizal fungi Symbiosis 76:139-149. 
Souza TAF, Santos D, Andrade LA, Farias H (2019) Feedback planta-solo de duas espécies de leguminosas no semi-árido brasileiro. Braz Jorn Microbiol (50):1011-1020.

https://doi.org/10.1007/s42770-019-00125-y

Stabile MC, Guimarães AL, Silva DS, Ribeiro V, Macedo MN, Coe, MT, Pinto E, Moutinho P, Alencar A (2020) Solving Brazil's land use puzzle: Increasing production and slowing Amazon deforestation. Land Use Policy, 91, 104362. https://doi.org/10.1016/j.landusepol.2019.104362

Teixeira PC, Donagemma GK, Fontana A, Teixeira WG (2017) Manual de métodos de análise do solo. Embrapa Solos, Brasília.

Teófilo TMS, Mendes KF, Fernandes BCC, Oliveira FS, Silva TS, Takeshita V, Souza MF, Tornisielo VL, Silva DV (2020) Phytoextraction of diuron, hexazinone, and sulfometuron-methyl from the soil by green manure species. Chemosphere. https://doi.org/10.1016/j.chemosphere.2020.127059

Torres MARR, Carbonell-Bojollo RM, Moreno-García M, Ordóñez-Fernández R, Rodríguez-Lizana A (2021) Soil organic matter and nutrient improvement through cover crops in a Mediterranean olive orchard. Soil and Tillage Research. https://doi.org/10.1016/j.still.2021.104977

Vinholis MDMB, Saes MSM, Carrer MJ, de Souza Filho HM (2021) The effect of meso-institutions on adoption of sustainable agricultural technology: A case study of the Brazilian Low Carbon Agriculture Plan. Journal of Cleaner Production, 280, 124334. https://doi.org/10.1016/j.jclepro.2020.124334

Wang L, Palta JA, Chen W, Chen Y, Deng X (2018) Nitrogen fertilization improved water-use efficiency of winter wheat through increasing water use during vegetative rather than grain filling. Agricultural Water Management 197:41-53. https://doi.org/10.1016/j.agwat.2017.11.010

Wang W, Wang Z, Yang K, Wang P, Wang H, Guo L, Zhu S, Zhu Y, He X. (2020). Biochar Application Alleviated Negative Plant-Soil Feedback by Modifying Soil Microbiome. Frontiers in Microbiology, 11. https://doi.org/10.3389/fmicb.2020.00799

WRB - IUSS Working Group (2006) World Reference Base for Soil. World Soil Resources Reports. Rome: FAO

Xavier PB and Vieira HD (2018) Physiological potential of seeds of Perennial Soybean cv. Comum Coated with different materials. American Journal of Plant Sciences 9(1):1-12.

https://doi.org/10.4236/ajps.2018.91001

Yang, T., Siddique, K. H. M., Liu, K. (2020) Cropping systems in agriculture and their impact on soil healthA review. Global Ecology and Conservation, 23(e01118). https://doi.org/10.1016/j.gecco.2020.e01118 
Zhang D, Yao P, Zhao N, Cao W, Zhang S, Li Y, Huang D, Zhai B, Wang Z, Gao Y (2019) Building up the soil carbon pool via the cultivation of green manure crops in the Loess Plateau of China. Geoderma 337:425433. https://doi.org/10.1016/j.geoderma.2018.09.053

Zhou G, Gaoc S, Lud Y, Liaod Y, Nied J, Weidong Cao (2020) Co-incorporation of green manure and rice straw improves rice production, soil chemical, biochemical and microbiological properties in a typical paddy field in southern China. Soil \& Tillage Research, 197, 104499.

https://doi.org/10.1016/j.still.2019.104499

\section{Figures}




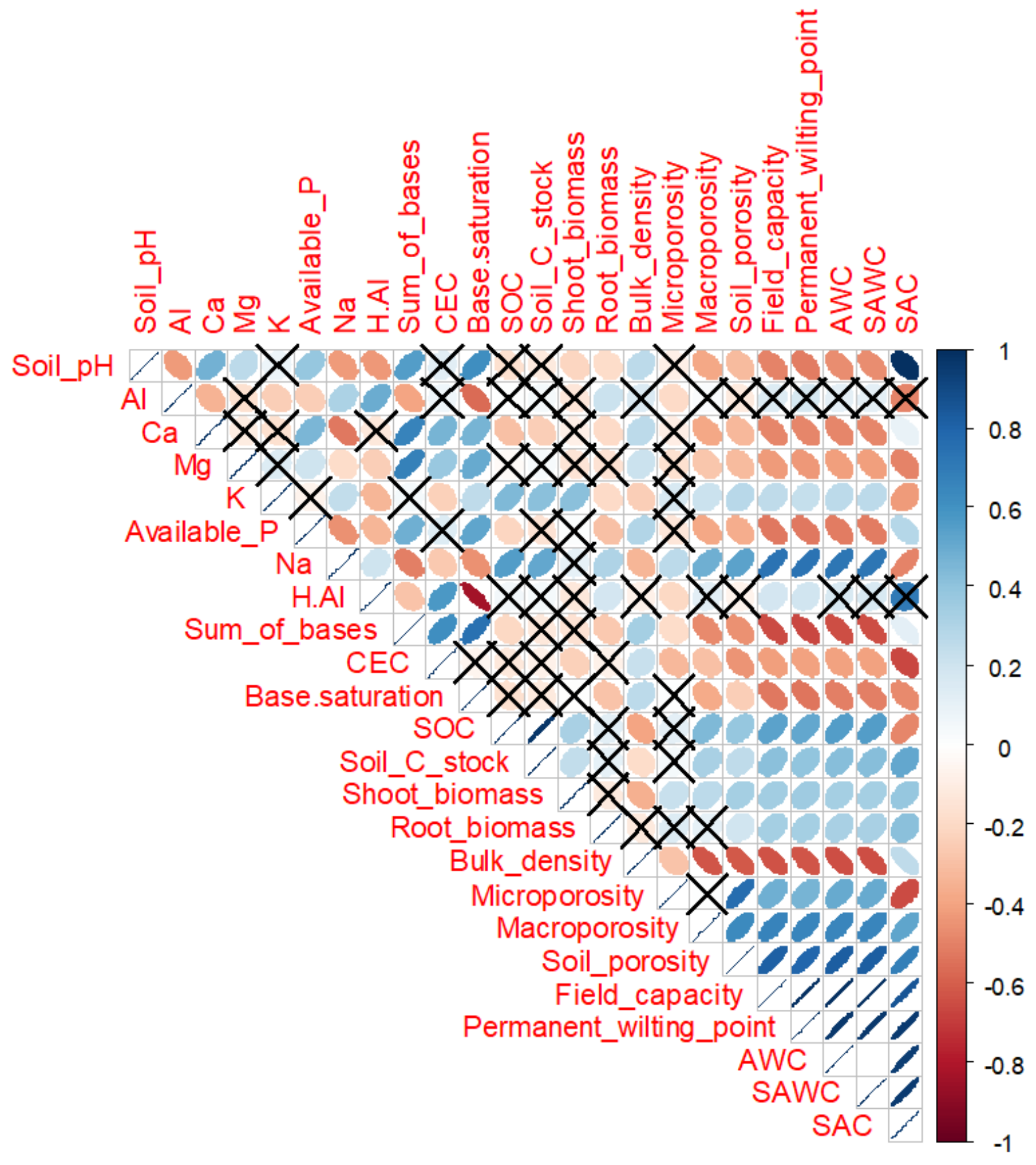

Figure 1

Correlation among the soil properties of plant species used as green manure in tropical ecosystem, Areia, Paraiba, Brazil. Data $=$ Mean \pm SD. No-significative effect are represented by $\times . S O C=$ Soil organic carbon; $A W C=$ available water content SAWC = soil available water capacity; and SAC = soil aeration capacity. 
(a)

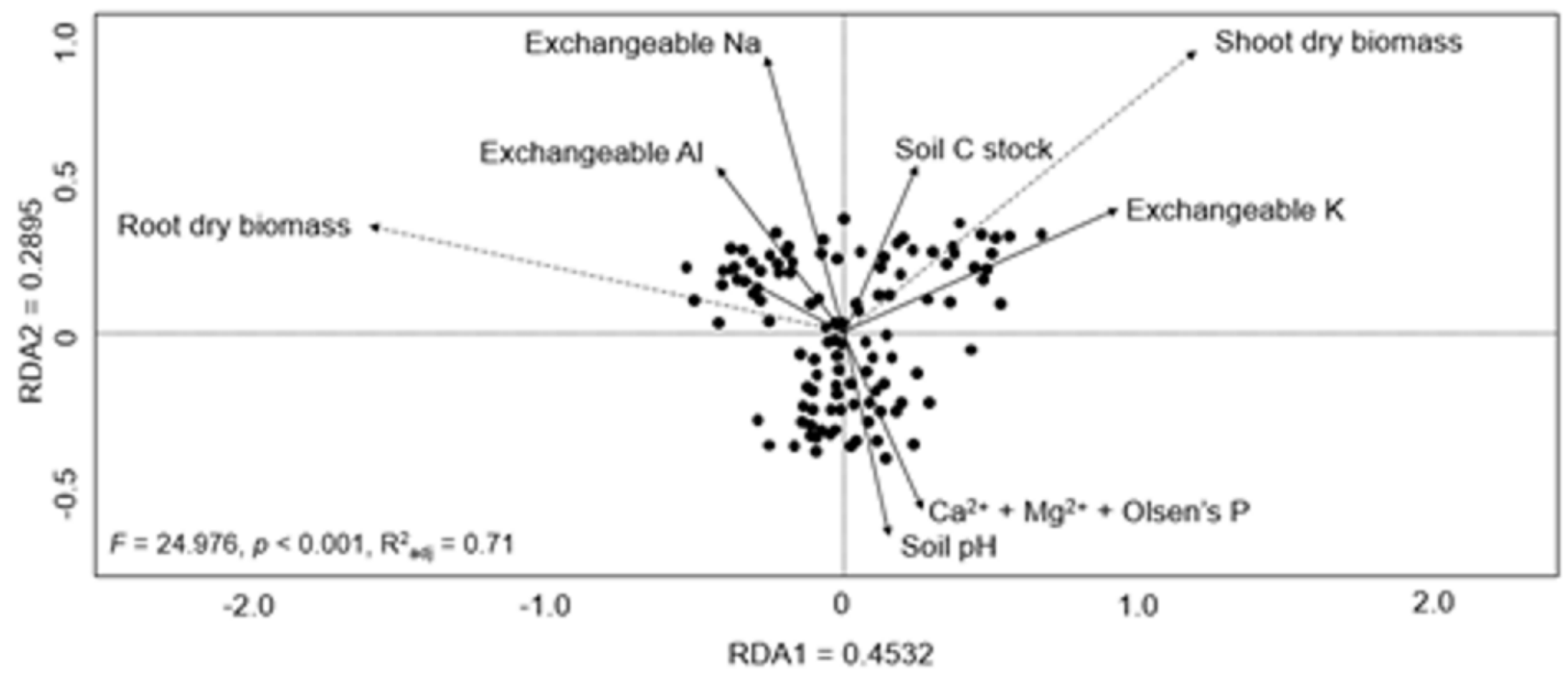

(b)

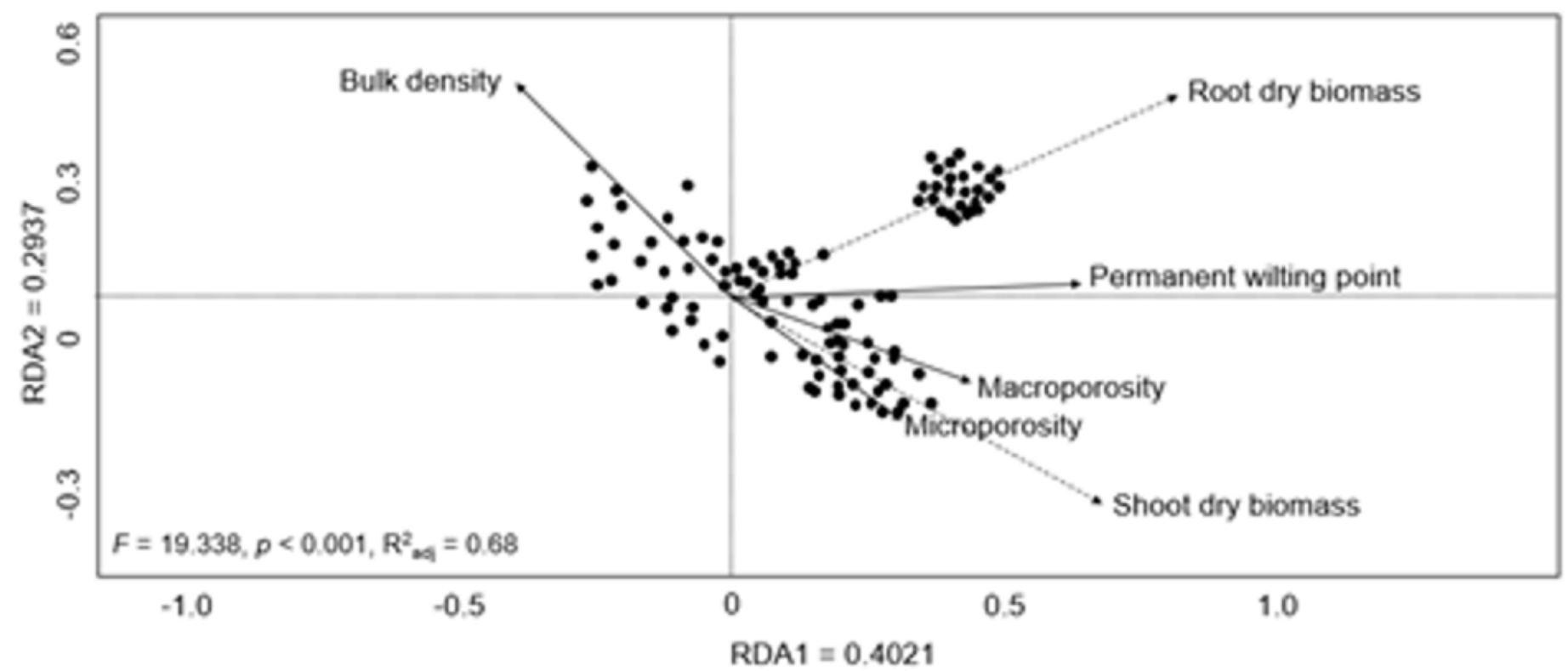

Figure 2

Redundancy analyses (RDA) ordination diagram for the relationship between primary production (shoot and root dry biomass) and soil chemical (a) and physical (b) properties. 


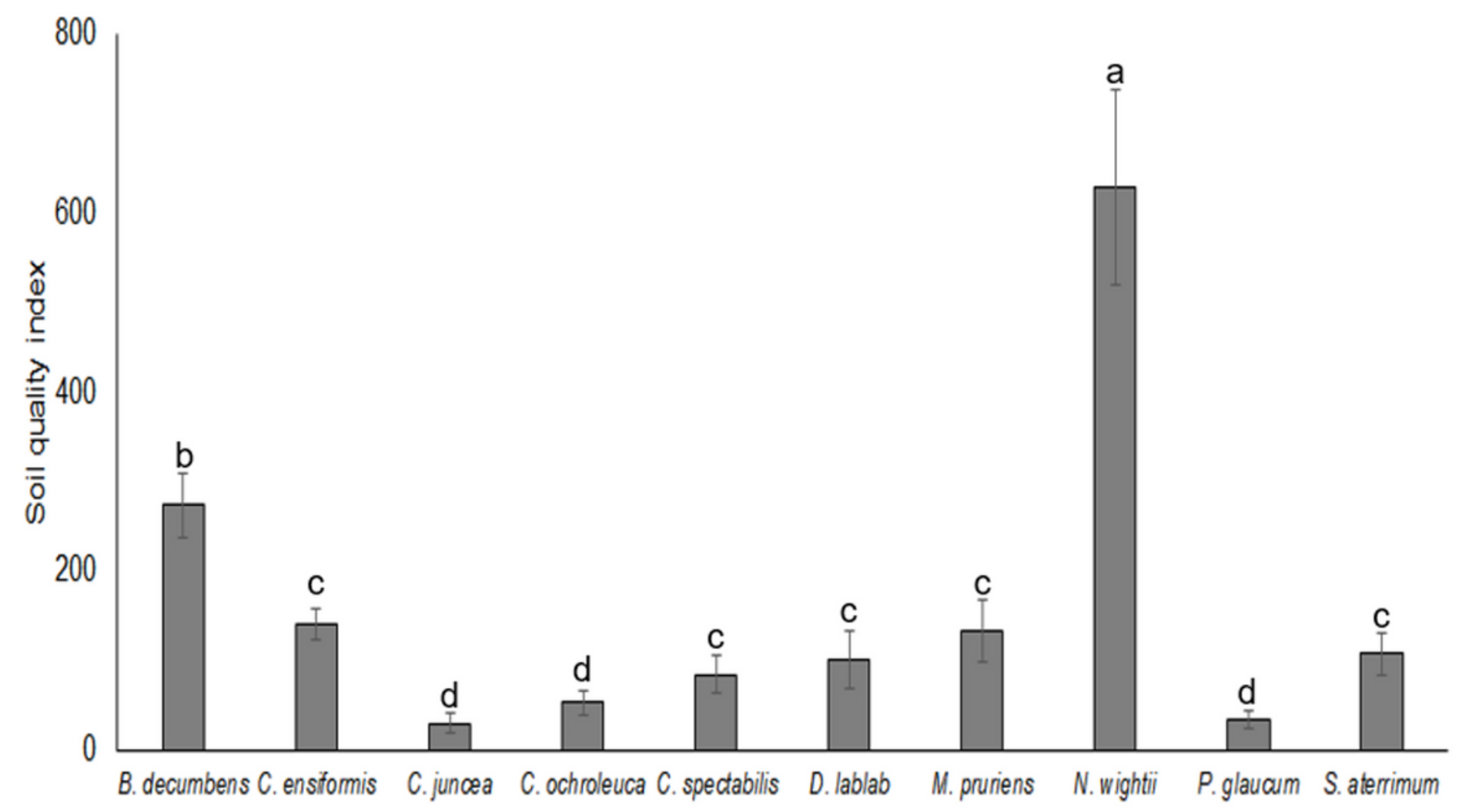

Figure 3

Soil biological quality index of different green manure plant species from the Brazilian semi-arid 